\title{
LANNEA DISCOLOR: ITS BOTANY, ETHNOMEDICINAL USES, PHYTOCHEMISTRY, AND PHARMACOLOGICAL PROPERTIES
}

\author{
ALFRED MAROYI* \\ Medicinal Plants and Economic Development (MPED) Research Centre, Department of Botany, University of Fort Hare, Private Bag X1314, \\ Alice 5700, South Africa. Email: amaroyi@ufh.ac.za \\ Received: 25 May 2018, Revised and Accepted: 25 June 2018
}

\begin{abstract}
Lannea discolor is an important component of the traditional, complementary, and alternative medicine health-care systems in several countries. This study is aimed at reviewing the botany, ethnomedicinal uses, phytochemical and biological activities of $L$. discolor. Information on its botany, medicinal uses, chemistry and pharmacological properties was undertaken using electronic databases such as Pubmed, SCOPUS, Medline, SciFinder, ScienceDirect, Google Scholar, EThOS, ProQuest, OATD and Open-thesis. Pre-electronic literature was sourced from the University Library. The species is used as herbal medicine for 24 human diseases. The major diseases and ailments treated using concoctions prepared from $L$. discolor include gastrointestinal problems, gonorrhea, infertility in women, convulsions, dizziness, injury, and wounds. Different aqueous and organic extracts of $L$. discolor exhibited anthelmintic, antibacterial, antimycobacterial, antifungal, antioxidant, antiplasmodial, and nematicidal activities. Detailed studies on the phytochemistry, pharmacological, and toxicological properties of $L$. discolor are required to correlate the medicinal uses of the species with its phytochemistry and pharmacological properties.
\end{abstract}

Keywords: Alternative, complementary and traditional medicine, Anacardiaceae, Ethnopharmacology, Lannea discolor, Southern Africa.

(C) 2018 The Authors. Published by Innovare Academic Sciences Pvt Ltd. This is an open access article under the CC BY license (http://creativecommons. org/licenses/by/4. 0/) DOI: http://dx.doi.org/10.22159/ajpcr.2018.v11i10.27523

\section{INTRODUCTION}

Lannea discolor (Sond.) Engl. is an important component of complementary and alternative medicine and traditional primary healthcare systems in several countries in Sub-Saharan Africa. The World Health Organization defined traditional medicine as the sum total of traditional or indigenous knowledge, skills, and practices of local cultures used to diagnose, prevent, treat, and maintain physical and mental illnesses [1]. Traditional medicine that has been adopted from other cultures is often referred to as complementary or alternative medicine [1]. The terms traditional, complementary, and alternative medicines are often used interchangeably in some countries. Plants with medicinal properties are popular and widely used in tropical Africa as about $80 \%$ of the people in developing countries are still reliant on traditional, complementary, or alternative medicines to fulfill their primary health care needs and also due to cultural tradition or lack of alternatives [2]. Currently, traditional, complementary, or alternative medicines are getting significant attention in ethnopharmacological research as $25 \%$ of pharmaceutical drugs and products, $11 \%$ of prescription drugs which are regarded by the World Health Organization as essential to human health are prepared from herbal medicines, and also several synthetic drugs on the market today are derived from phytochemical compounds obtained from medicinal plants [3]. Although there is an increasing acceptance of traditional, complementary, or alternative medicines in treating and managing human diseases and ailments in developing countries [4-33], this traditional knowledge on herbal medicines is not adequately documented. $L$. discolor is one of the important medicinal plants in Sub-Saharan Africa [7,34-36], but there is a dearth of information on phytochemical and pharmacological properties of the species. It is within this context that this review was undertaken aimed at summarizing the botany, medicinal uses, and phytochemical and pharmacological properties of L. discolor so as to provide baseline data required in evaluating the therapeutic potential of the species.

\section{BOTANICAL PROFILE OF L. DISCOLOR}

L. discolor is a species of the Lannea A. Rich. genus, belonging to the cashew or sumac or Anacardiaceae family. The Anacardiaceae family includes economically important genera such as cashew (Anacardium L.), mango (Mangifera L.), marula (Sclerocarya Hochst.), and sumac (Rhus L.), and the family comprises about 800 species in 82 genera [37]. The name of the genus "Lannea" is based on a Latin word "lana" which translates to "wool" in reference to young plant parts which are densely hairy or possibly to the wool on the roots of some Lannea species [38,39]. The specific name "discolor" is a Latin word meaning having two different colors in reference to the two colors of the leaflets, that is, glossy dark green above and silvery gray below [38,39]. The genus Lannea consists of approximately 40 species which are usually trees, shrubs, or suffrutices, occupying different habitats in SubSaharan Africa, Arabia, and Tropical Asia [40,41].

L. discolor is a deciduous tree growing up to an average height of $15 \mathrm{~m}$ with a rounded crown with a single upright or forked trunk [38]. The trunk is gray or reddish-gray and smooth with thick bark, smooth grayish branches, and sturdy, blunt, wrinkled, and hairy twigs. The branchlets are thick and densely covered with whitish hairs. The leaves are compound, oval- to egg-shaped, or almost round in shape. The young leaves are soft, pink, and furry; the adult leaflets are dark green above and velvety whitish gray below with conspicuous midrib and lateral veins [42]. The flowers are small, sweet-scented, creamyyellow in color and occur in spike-like inflorescence, grouped together, and crowded at the end of branches [43]. The fruit is smooth, fleshy, roundish- to egg-shaped, reddish to purple-black in color when ripe. L. discolor has been recorded in Namibia, Malawi, Swaziland, Angola, Mozambique, Zimbabwe, Botswana, Zambia, the Democratic Republic of Congo, and South Africa [44-50] in open grassland, bushveld, woodland, and often on rocky ridges or termitaria $[38,42,43]$.

\section{MEDICINAL USES OF L. DISCOLOR}

The bark, fruit pulp, leaves, stem bark, and roots of $L$. discolor possess medicinal properties and are used to treat and manage human ailments and diseases (Table 1). Based on literature, L. discolor is used to treat and manage 24 human diseases and ailments (Table 1 ). The leaf, bark, and root infusion of $L$. discolor is applied as poultices for abscesses in South Africa [35], boils in South Africa and Zambia [35,51], and 
sore eyes in South Africa and Zimbabwe [7,22,35]. The leaf, bark, and root infusion of $L$. discolor are taken orally against gastrointestinal problems including constipation, diarrhea, dysentery, and stomach ailments in Zimbabwe, Botswana, Zambia, South Africa, Malawi, Mozambique, Swaziland, and Namibia [7,9,34-36,51-55]. The root, leaf, and bark maceration of L. discolor are taken orally for convulsions, cough, fever, female infertility, gonorrhea, and menstrual problems in Zimbabwe, Malawi, Zambia, Mozambique, Swaziland, and South Africa [7,34-36,52,53,55-60]. In Zimbabwe, South Africa, and Namibia, the twigs and fibers of $L$. discolor are used as bandages for fractures and wounds, and root powder is also applied topically on swollen legs [7,35,54]. In Zimbabwe, bark, leaf, and root decoction of L. discolor are taken orally as a remedy for bilharzia, bladder problems, and malaria $[36,61,62]$ and the species is also used for protection against lightning and witchcraft [7]. In Swaziland, bark and root maceration of

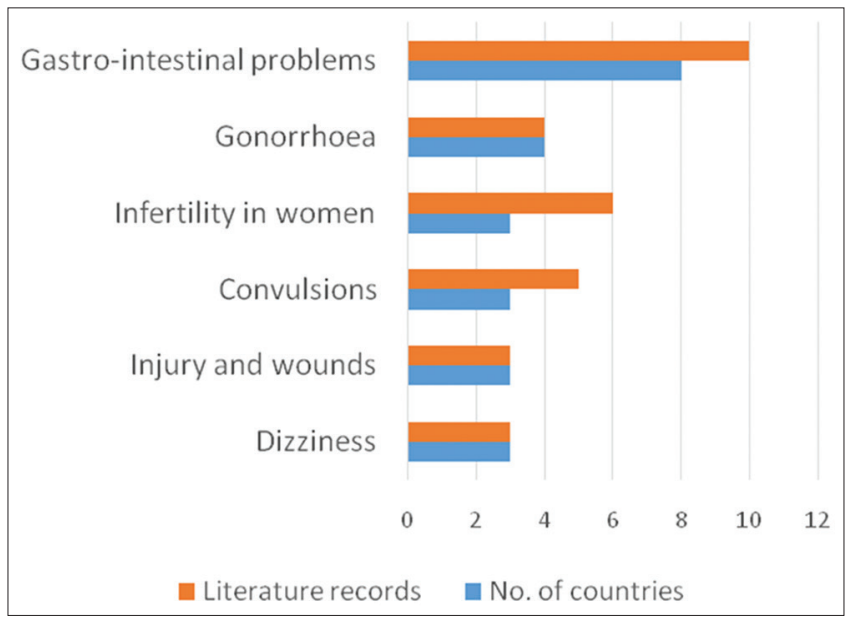

Fig. 1: Diseases treated by Lannea discolor
L. discolor is taken orally for bladder problems [34], while in Zambia, the leaf, bark, and root maceration of the species are taken orally for fits and applied topically for smallpox $[4,51]$. The major diseases treated using concoctions made from $L$. discolor include gastrointestinal problems, gonorrhea, infertility in women, convulsions, dizziness, injury, and wounds (Fig.1). Gastrointestinal disorders are a major concern in Tropical Africa as these medical conditions are characterized by high mortality rates when left untreated [63,64]. Research by Chinsembu [55] and Chinsembu et al. [53] revealed that traditional healers in Tropical Africa have good knowledge of how sexually transmitted infections including gonorrhea are treated and managed using herbal medicines. Similarly, antimicrobial evaluation of 25 medicinal plants used against gonorrhea in Rwanda showed that $64.0 \%$ of the tested species were active against Neisseria gonorrhoeae and other related pathogens that cause gonorrhea in humans [65].

\section{BIOLOGICAL ACTIVITIES AND PHYTOCHEMISTRY OF L. DISCOLOR}

Some of the biological activities of $L$. discolor listed in literature include anthelmintic [66], antibacterial [67], antimycobacterial [68], antifungal [67], antioxidant [69], antiplasmodial [70], and nematicidal activities [71]. These biological activities of various parts of the species are summarized below.

\section{Anthelmintic activities}

Mølgaard et al. [66] evaluated the anthelmintic activities of water root, stem, leaf and root bark extracts of $L$. discolor against newly excysted (cestodes) tapeworms, Hymenolepis diminuta. All the extracts killed the newly excysted cysticercoids during the $1^{\text {st }} \mathrm{h}$ of incubation in a culture medium. The lethal concentrations of $L$. discolor extracts varied from 1.2 to $12.9 \mathrm{mg} / \mathrm{mL}$ after $24 \mathrm{~h} \mathrm{[66]} \mathrm{as} \mathrm{shown} \mathrm{in} \mathrm{Table} \mathrm{2.} \mathrm{These} \mathrm{findings}$ are of ethnopharmacological importance in the traditional application of $L$. discolor as herbal medicine against bilharzia in Zimbabwe [61] and future research aimed at controlling and managing schistosomiasis in Sub-Saharan Africa and other regions [72]

Table 1: Ethnomedicinal applications of $L$. discolor

\begin{tabular}{|c|c|c|c|}
\hline Medicinal use & Parts of the plant used & Country & References \\
\hline Abscesses & Bark and leaf infusion applied topically & South Africa & [35] \\
\hline Bilharzia & Root decoction taken orally & Zimbabwe & [61] \\
\hline Bladder problems & Leaf, bark, and root infusion taken orally & Zimbabwe, Swaziland & {$[34,36]$} \\
\hline Boils & $\begin{array}{l}\text { Bark, leaf, and root maceration applied } \\
\text { topically }\end{array}$ & Zambia, South Africa & {$[35,51]$} \\
\hline Constipation & Bark, leaf, and root maceration taken orally & Zimbabwe & [36] \\
\hline Convulsions & Leaf, bark, and root infusion taken orally & Zimbabwe, South Africa, Swaziland & {$[7,34-36,59]$} \\
\hline Diarrhea & $\begin{array}{l}\text { Bark, fruit pulp, root, and stem bark } \\
\text { decoction taken orally }\end{array}$ & $\begin{array}{l}\text { Zimbabwe, Malawi, Botswana, South Africa, } \\
\text { Mozambique, Swaziland, Namibia, Zambia, } \\
\text { Zimbabwe }\end{array}$ & {$[7,9,34-36,52-55]$} \\
\hline Dizziness & Leaf, bark, and root infusion taken orally & South Africa, Swaziland, Zimbabwe & [34-36] \\
\hline Dysentery & Leaf and bark infusion taken orally & Zambia & [51] \\
\hline Fever & Leaf, bark, and root infusion taken orally & Zambia, Zimbabwe & {$[36,56]$} \\
\hline Fits & Bark and leaf decoction taken orally & Zambia & {$[4,51]$} \\
\hline Fractures & Twigs and fibers used as bandage & South Africa, Zimbabwe & {$[7,35]$} \\
\hline Gonorrhea & Root decoction taken orally & South Africa, Zambia, Zimbabwe & {$[7,35,55]$} \\
\hline Infertility in women & Leaf, bark, and root infusion taken orally & Zimbabwe, South Africa, Mozambique & {$[7,35,36,53,57,58]$} \\
\hline Malaria & Leaf, bark, and root infusion taken orally & Zimbabwe & {$[36,62]$} \\
\hline Menstrual problems & Root and bark infusion taken orally & Zimbabwe, South Africa & {$[7,35,60]$} \\
\hline Smallpox & Root decoction taken orally & Zambia & {$[51]$} \\
\hline Sore eyes & Leaf and root infusion applied to eyes & South Africa, Zimbabwe & {$[7,22,35]$} \\
\hline Stomach problems & Leaf, bark, and root infusion taken orally & Zimbabwe, Malawi, Swaziland & {$[34,36,52]$} \\
\hline Swollen legs & Root powder applied topically & South Africa, Zimbabwe & {$[7,35]$} \\
\hline Witchcraft/lightning & $\begin{array}{l}\text { Root powder taken orally or ointment } \\
\text { buried around homestead }\end{array}$ & Zimbabwe & [7] \\
\hline Wounds & Fibers used as bandage & Namibia, Zimbabwe & {$[7,54]$} \\
\hline
\end{tabular}

L. discolor: Lannea discolor 
Table 2: Biological properties of $L$. discolor extracts

\begin{tabular}{|c|c|c|c|c|c|}
\hline Activity tested & Extract & Plant part & Model & Effect & Reference \\
\hline \multirow[t]{2}{*}{ Anthelmintic } & Water & Leaves and stem & Cestode model & $\begin{array}{l}\text { Active against cestodes of } \\
\text { Hymenolepis diminuta, lethal } \\
\text { concentration varying from } 10.0 \\
\text { to } 2.5 \mathrm{mg} / \mathrm{ml}\end{array}$ & {$[70]$} \\
\hline & & Root and root bark & Cestode model & $\begin{array}{l}\text { Active against cestodes of } \\
\text { Hymenolepis diminuta, lethal } \\
\text { concentration varying from } 12.9 \\
\text { to } 1.2 \mathrm{mg} / \mathrm{ml}\end{array}$ & {$[70]$} \\
\hline \multirow[t]{2}{*}{ Antibacterial } & $\begin{array}{l}\text { Dichlomethane: } \\
\text { methanol (1:1) }\end{array}$ & Leaf & $\begin{array}{l}\text { Microtiter plate } \\
\text { dilution }\end{array}$ & $\begin{array}{l}\text { Active against Brevibacillus } \\
\text { agri with MIC value of } 1.0 \\
\mathrm{mg} / \mathrm{ml} \text {, Propionibacterium } \\
\text { acnes }(1.0 \mathrm{mg} / \mathrm{ml}), \text { Pseudomonas } \\
\text { aeruginosa }(1.0 \mathrm{mg} / \mathrm{ml}) \text {, } \\
\text { Staphylococcus aureus }(2.0 \\
\mathrm{mg} / \mathrm{ml}), \mathrm{MRSA}(1.0 \mathrm{mg} / \mathrm{ml}) \text {, } \\
\text { GMRSA }(2.0 \mathrm{mg} / \mathrm{ml}), \text { and } \\
\text { Staphylococcus epidermidis } \\
(2.0 \mathrm{mg} / \mathrm{ml})\end{array}$ & {$[67]$} \\
\hline & Water & Leaf & $\begin{array}{l}\text { Microtiter plate } \\
\text { dilution }\end{array}$ & $\begin{array}{l}\text { Active against Brevibacillus agri } \\
\text { with } \mathrm{MIC} \text { value of } \\
4.0 \mathrm{mg} / \mathrm{ml} \text {, Propionibacterium } \\
\text { acnes }(1.0 \mathrm{mg} / \mathrm{ml}), \text { Pseudomonas } \\
\text { aeruginosa }(12.0 \mathrm{mg} / \mathrm{ml}) \text {, } \\
\text { Staphylococcus aureus } \\
(16.0 \mathrm{mg} / \mathrm{ml}), \text { MRSA } \\
(16.0 \mathrm{mg} / \mathrm{ml}), \text { GMRSA } \\
(4.0 \mathrm{mg} / \mathrm{ml}) \text {, and Staphylococcus } \\
\text { epidermidis }(16.0 \mathrm{mg} / \mathrm{ml})\end{array}$ & {$[67]$} \\
\hline Antifungal & $\begin{array}{l}\text { Dichlomethane: } \\
\text { methanol (1:1) }\end{array}$ & Leaf & $\begin{array}{l}\text { Microtiter plate } \\
\text { dilution }\end{array}$ & $\begin{array}{l}\text { Active against Candida albicans } \\
\text { with MIC value of } \\
2.0 \mathrm{mg} / \mathrm{ml} \text {, Microsporum canis } \\
\text { (4.0 mg/ml), and Trichophyton } \\
\text { mentagrophytes }(0.05 \mathrm{mg} / \mathrm{ml})\end{array}$ & [67] \\
\hline Antimycobacterial & Methanol & Leaves & Microdilution assay & $\begin{array}{l}\text { Extracts active Mycobacterium } \\
\text { bovis with MIC value of } \\
0.11 \mathrm{mg} / \mathrm{ml} \text {, multidrug-resistant } \\
\text { Mycobacterium tuberculosis } \\
(0.52 \mathrm{mg} / \mathrm{ml}) \text {, avirulent } \\
\text { strain, H37Ra Mycobacterium } \\
\text { tuberculosis }(0.11 \mathrm{mg} / \mathrm{ml}), \\
\text { Mycobacterium smegmatis, } \\
\text { Mycobacterium fortuitum, and } \\
\text { Mycobacterium aurum with MIC } \\
\text { values of } 0.21 \mathrm{mg} / \mathrm{ml}\end{array}$ & {$[68]$} \\
\hline Antioxidant & Methanol & Bark, root & $\begin{array}{l}\text { DPPH free radical } \\
\text { scavenging, reducing } \\
\text { power effects, and } \\
\beta \text {-carotene linoleic } \\
\text { acid assays }\end{array}$ & $\begin{array}{l}\text { Bark and root extracts showed } \\
\text { ability to scavenge DPPH, reduce } \\
\text { ferric ions, and delay bleaching of } \\
\beta \text {-carotene }\end{array}$ & [69] \\
\hline \multirow[t]{3}{*}{ Antiplasmodial } & Dichloromethane & Fruits & pLDH assay & $\begin{array}{l}\text { Active against Plasmodium } \\
\text { falciparum with } \mathrm{IC}_{50} \text { value of } \\
25 \mu \mathrm{g} / \mathrm{ml}\end{array}$ & {$[70]$} \\
\hline & $\begin{array}{l}\text { Dichloromethane: } \\
\text { methanol }(1: 1)\end{array}$ & Fruits & pLDH assay & $\begin{array}{l}\text { Weak activity against Plasmodium } \\
\text { falciparum with } \mathrm{IC}_{50} \\
\text { value }>100 \mu \mathrm{g} / \mathrm{ml}\end{array}$ & {$[70]$} \\
\hline & Water & Fruits & pLDH assay & $\begin{array}{l}\text { Weak activity against } \\
\text { Plasmodium falciparum with } \mathrm{IC}_{50} \\
\text { value }>100 \mu \mathrm{g} / \mathrm{ml}\end{array}$ & {$[70]$} \\
\hline
\end{tabular}


Table 2: (Continued)

\begin{tabular}{|c|c|c|c|c|c|}
\hline Activity tested & Extract & Plant part & Model & Effect & Reference \\
\hline \multirow[t]{2}{*}{ Nematicidal } & Acetone & Bark & Growth inhibition & Reduced root galling by $40 \%$ & {$[71]$} \\
\hline & Water & Bark & Growth inhibition & Reduced root galling by $45 \%$ & [71] \\
\hline Cytotoxicity & Ethanol & Leaf & $\begin{array}{l}\text { MTT assay against } \\
\text { Vero, hepatoma, and } \\
\text { mouse macrophage } \\
\text { cells }\end{array}$ & $\begin{array}{l}\text { Showed low toxicity with } \mathrm{LC}_{50} \text { value } \\
\text { of } 0.408 \mathrm{mg} / \mathrm{mL} \text { and }>1.0 \mathrm{mg} / \mathrm{mL} \\
\text { againstliverandmurinemacrophage } \\
\text { cells, respectively }\end{array}$ & [68] \\
\hline
\end{tabular}

L. discolor: Lannea discolor, MIC: Minimum inhibitory concentration, MRSA: Methicillin-resistant Staphylococcus aureus, GMRSA: Gentamicin-methicillin-resistant Staphylococcus aureus, DPPH: 2, 2-diphenyl-1-picrylhdrazyl, MTT: 3-(4, 5-dimethylthiazol)-2, 5-diphenyl tetrazolium bromide, LC $_{50}$ : Median lethal concentration, $\mathrm{IC}_{50}$ : Half maximal inhibitory concentration

Table 3: Nutritional and phytochemical composition of bark, leaves, and roots of $L$. discolor

\begin{tabular}{|c|c|c|c|}
\hline Nutritional composition & Values & Plant parts & References \\
\hline Acid detergent fiber (g/100 g dry matter) & 41.2 & Leaves & [72] \\
\hline Acid detergent lignin (g/100 g dry matter) & 17.9 & Leaves & [72] \\
\hline As $(\mathrm{mg} / \mathrm{kg})$ & $0.11-0.12$ & Leaves, roots & [36] \\
\hline Ash (g/100 g dry matter) & 10.6 & Leaves & [72] \\
\hline $\mathrm{Ca}(\mathrm{g} / 100 \mathrm{~g}$ dry matter) & 2.6 & Leaves & [72] \\
\hline Cellulose (g/100 g dry matter) & 23.2 & Leaves & [72] \\
\hline Crude protein (g/100 g dry matter) & 14.3 & Leaves & [72] \\
\hline Dry matter $(\%)$ & 33.9 & Leaves & [72] \\
\hline $\mathrm{Fe}(\mathrm{mg} / \mathrm{kg})$ & $3.44-4.65$ & Leaves, roots & [36] \\
\hline Flavonoid content (mg CTE/g) ${ }^{\mathrm{a}}$ & $2.18-2.97$ & Bark & [71] \\
\hline Hemi-cellulose (g/100 g dry matter) & 14.2 & Leaves & [73] \\
\hline In vitro of organic matter (\%) & 49.3 & Leaves & [73] \\
\hline $\mathrm{K}(\mathrm{g} / 100 \mathrm{~g}$ dry matter $)$ & 0.5 & Leaves & [73] \\
\hline Metabolizable energy (MJ/Kg dry matter) & 6.7 & Leaves & [73] \\
\hline $\operatorname{Mg}(\mathrm{g} / 100 \mathrm{~g}$ dry matter) & 0.64 & Leaves & [73] \\
\hline Neutral detergent fiber (g/100 g dry matter) & 55.4 & Leaves & [73] \\
\hline $\mathrm{Ni}(\mathrm{mg} / \mathrm{kg})$ & $0.01-0.05$ & Leaves, roots & [36] \\
\hline P (g/100 g dry matter) & 0.13 & Leaves & [73] \\
\hline $\mathrm{Pb}(\mathrm{mg} / \mathrm{kg})$ & $0.55-0.60$ & Leaves, roots & [36] \\
\hline Proanthocyanidin (\%L CE/g dry matter) ${ }^{\mathrm{b}}$ & $1.25-3.23$ & Bark & [71] \\
\hline Tannin content (mg/ml gallic acid equivalent) & 4.0 & Leaves & [74] \\
\hline Total phenolic content $(\mathrm{mg} \mathrm{GAE} / \mathrm{g})^{\mathrm{c}}$ & $21.69-60.0$ & Bark, roots & {$[69,71]$} \\
\hline $\mathrm{Zn}(\mathrm{mg} / \mathrm{kg})$ & $0.73-0.83$ & Leaves, roots & [36] \\
\hline
\end{tabular}

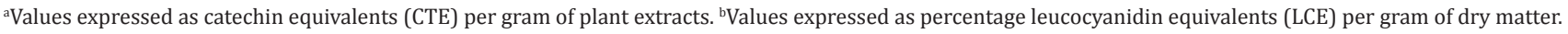

${ }^{\mathrm{c}}$ Values expressed as gallic acid equivalent (GAE) per gram of dry matter. L. discolor: Lannea discolor

\section{Antibacterial activities}

Mabona et al. [67] evaluated antibacterial activities of water and dichlomethane:methanol (1:1) leaf extracts of $L$. discolor using the micro dilution technique against dermatologically relevant pathogens such as Brevibacillus agri, Staphylococcus aureus, Propionibacterium acnes, Pseudomonas aeruginosa, methicillin-resistant Staphylococcus aureus (MRSA), gentamycin-methicillin-resistant Staphylococcus aureus (GMRSA) and Staphylococcus epidermidis with ciprofloxacin as positive control and acetone and dimethylsulfoxide (DMSO) as negative controls. All the extracts demonstrated some activities with minimum inhibition concentration (MIC) values ranging from $1.0 \mathrm{mg} / \mathrm{mL}$ to 16.00 $\mathrm{mg} / \mathrm{mL}$ (Table 2). These antibacterial activities exhibited by different extracts of $L$. discolor support the application of the plant as remedy for bacterial pathogens causing abscesses in South Africa [35], boils in South Africa and Zambia [35,51], diarrhoea in Malawi, Botswana, Zimbabwe, Mozambique, Zambia, Namibia, Swaziland and South Africa [7,9,34-36,52-55], dysentery in Zambia [51], gonorrhoea in Zimbabwe, Malawi, Zambia and South Africa $[7,35,52,55]$, stomach problems in Malawi, Swaziland and Zimbabwe [34,36,52] and wounds in Namibia and Zimbabwe [7,54].

\section{Antimycobacterial activities}

Kabongo-Kayoka et al. [68] evaluated antimycobacterial activities of leaf extracts of $L$. discolor using a microdilution assay against the pathogenic Mycobacterium bovis, multidrug resistant Mycobacterium tuberculosis, avirulent strain, H37Ra Mycobacterium tuberculosis, Mycobacterium fortuitum, Mycobacterium smegmatis and Mycobacterium aurum with ciprofloxacin, rifampicin, isoniazid and streptomycin as positive controls. The extracts demonstrated activities with MIC values ranging from $0.11 \mathrm{mg} / \mathrm{ml}$ to $0.52 \mathrm{mg} / \mathrm{ml}$ (Table 2). These findings corroborate the medicinal use of $L$. discolor in the treatment of respiratory system disorders including cough in South Africa and Zimbabwe $[7,35]$.

\section{Antifungal activities}

Mabona et al. [67] assessed antifungal properties of water and dichlomethane:methanol (1:1) leaf extracts of $L$. discolor using the microtitre plate dilution technique against dermatologically relevant pathogens such as Candida albicans, Trichophyton mentagrophytes and Microsporum canis with amphotericin B as positive control and acetone and dimethylsulfoxide (DMSO) as negative controls. The extracts demonstrated some activities with MIC values ranging from $0.05 \mathrm{mg} /$ $\mathrm{mL}$ to $16.00 \mathrm{mg} / \mathrm{mL}$ (Table 2). These findings support the medicinal use of $L$. discolor against fungal and microbial infections such as wounds in Namibia and Zimbabwe [7,54].

\section{Antioxidant activities}

Chakuma et al. [69] evaluated antioxidant activities of root and bark extracts of $L$. discolor using 2, 2-diphenyl-1-picrylhdrazyl (DPPH) free radical scavenging, reducing power effects and $\beta$-carotene linoleic acid assays with ascorbic acid as the standard. The bark extracts exhibited better ability to scavenge DPPH when compared to the root extract and ascorbic acid, the standard. Therefore, root and bark extracts of $L$. 
discolor were able to donate hydrogen and consequently reduce DPPH radicals [69]. The bark extract had better reducing power activities in comparison with the root extract, and the root, bark extracts, and the standard demonstrated concentration-dependant reducing power properties. The reducing power activities of the extracts and the standard increased as the concentration of the samples increased. The bark extracts exhibited the best ability to delay bleaching of $\beta$-carotene while the standard, ascorbic acid exhibited the least properties [69]. These documented antioxidant activities of the species are probably caused by the flavonoids and phenolics that have been identified from the bark (Table 3) of the species by Chakuna et al. [69] and Nyoni et al. [71].

\section{Antiplasmodial activities}

Clarkson et al. [70] evaluated the antiplasmodial activities of dichloromethane, water and dichloromethane/methanol (1:1) fruit extracts of $L$. discolor against Plasmodium falciparum using the parasite lactate dehydrogenase assay. The dichloromethane extract showed weak activities with half maximal inhibitory concentration (IC50) value of $25 \mu \mathrm{g} / \mathrm{ml}$. The weak antiplasmodial activities exhibited by L. discolor show that the plant could serve as an antimalarial agent. L. discolor is used as a remedy for malaria in Zimbabwe [36,62].

\section{Nematicidal activities}

Nyoni et al. [71] evaluated the nematicidal activities of acetone and aqueous bark extracts of $L$. discolor against Meloidogyne javanica.r plant. The extracts were screened on nematode inoculated tomato variety red khaki (Solanum lycopersicum L.) at a rate of $30 \mathrm{ml}$ per plant with fenamiphos (nemacur $400 \mathrm{~g} / \mathrm{l}$ ) used as a positive control at a rate of $30 \mathrm{ml}$ per plant. The extracts reduced the formation of root knot galls by $40-45 \%$ (Table 2 ). These findings revealed that $L$. discolor extracts have potential as nematicides and the species can be used by resourcepoor rural farmers to suppress and control the attack of tomato plants by nematodes.

\section{CYTOTOXICITY}

Kabongo-Kayoka et al. [68] evaluated cytotoxicity activities of leaf extracts of $L$. discolor using a 3-(4, 5-dimethylthiazol)-2, 5-diphenyl tetrazolium bromide (MTT) assay against Vero African monkey kidney cells, cancer liver cells and mouse macrophage cells (Table 2). The extracts exhibited low toxicity against the three cell lines with the median lethal concentration values ranging from $0.408 \mathrm{mg} / \mathrm{mL}$ to $>1.0 \mathrm{mg} / \mathrm{mL}$ (Table 2). These results may serve as an indication that $L$. discolor may be safe to use as herbal medicine.

A variety of minerals such as arsenic (As), calcium (Ca), copper (Cu), iron $(\mathrm{Fe})$, lead $(\mathrm{Pb})$, magnesium $(\mathrm{Mg})$, nickel $(\mathrm{Ni})$, phosphorus $(\mathrm{P})$, potassium $(\mathrm{K})$ and Zinc $(\mathrm{Zn})$ have been identified from the leaves and roots of L. discolor [36,73] (Table 3). It has been reported that minerals such as $\mathrm{Ca}, \mathrm{Cu}, \mathrm{Fe}, \mathrm{Mg}, \mathrm{P}, \mathrm{K}$, and $\mathrm{Zn}$ are essential nutrients required for various biochemical and physiological processes [75]. However, heavy metals such as $\mathrm{As}, \mathrm{Ni}$, and $\mathrm{Pb}$ have no established biological functions and considered non-essential elements [36,75-78]. Therefore, rigorous quality control of $L$. discolor products for toxic heavy metals is required aimed at ensuring that heavy metal contamination is kept to a minimum.

\section{CONCLUSION}

Based on its wide use as traditional medicine in southern Africa, L. discolor should be subjected to rigorous ethnopharmacological evaluation aimed at elucidating its chemical, pharmacological, and toxicological properties. Non-essential heavy metals such as arsenic, lead, and nickel were identified from leaves and roots, the plant parts which are used to prepare herbal concoctions. This calls for detailed target-organ toxicity studies involving $L$. discolor and its derivatives aimed at establishing any side effects associated with utilization of the species as herbal medicine.

\section{AUTHORS' CONTRIBUTIONS}

I declare that this work was done by the author named in this article.

\section{CONFLICTS OF INTEREST}

No conflict of interest is associated with this work.

\section{REFERENCES}

1. World Health Organization. Traditional, Complementary and Integrative Medicine; 2017. Available from: http://www.who.int/ traditional-complementary-integrative-medicine/about/en/.

2. World Health Organization. WHO Traditional Medicine Strategy 2002-2005; 2002. Available from: http:/www.wpro.who.int/health technology/book_who_traditional_medicine_strategy_2002_2005.pdf.

3. Rates SM. Plants as source of drugs. Toxicon 2001;39:603-13.

4. Watt JM, Breyer-Brandwijk MG. The Medicinal and Poisonous Plants of Southern and Eastern Africa. Edinburgh: E and S Livingstone Ltd.; 1962.

5. Sofowora A. Medicinal Plants and Traditional Medicine in Africa. Chichester: Wiley; 1982.

6. Farnsworth NR, Akerele OA, Soejarto DD, Guo Z. Medicinal plants in therapy. Bull World Health Organ 1985;63:965-81.

7. Gelfand M, Mavi S, Drummond RB, Ndemera B. The Traditional Medicine Practitioner in Zimbabwe: His Principles of Practice and Pharmacopoeia. Gweru: Mambo Press; 1985.

8. Oliver-Bever B. Medicinal Plants of Tropical West Africa. Cambridge: Cambridge University Press; 1986.

9. Hedberg I, Staugård F. Traditional Medicine in Botswana: Traditional Medicinal Plants. Gaborone: Ipelegeng Publishers; 1989.

10. Cunningham AB. African Medicinal Plants: Setting Priorities at the Interface between Conservation. Paris: UNESCO; 1993.

11. Kokwaro JO. Medicinal Plants of East Africa. Nairobi: East Africa Literature Bureau; 1993.

12. Burkill HM. The Useful Plants of West Tropical Africa. London: Royal Botanic Gardens, Kew; 1995

13. Hostettmann K, Marston A, Ndjoko K, Wolfender JL. The potential of African medicinal plants as a source of drugs. Curr Organic Chem 2000;4:973-1010.

14. Neuwinger HD. African Traditional Medicine: A Dictionary of Plant use and Applications. Stuttagart: Medpharm Scientific Publishers; 2000.

15. Arnold TH, Prentice GA, Hawker LC, Snyman EE, Tomalin M, Crouch NR, et al. Medicinal and Magical Plants of Southern Africa: An Annotated Checklist. Pretoria: Strelitzia 13, National Botanical Institute; 2002

16. Gurib-Fakim A, Brendler T. Medicinal and aromatic plants of Indian Ocean Islands: Madagascar, Comores, Seychelles and Mascarenes. Stuttgart: Medpharm Scientific Publishers; 2004.

17. Van Wyk BE, Wink M. Medicinal Plants of the World. Pretoria: Briza Publications; 2004

18. Elujoba A, Odeleye O, Ogunyemi C. Traditional medicine development for medicinal and dental primary health care delivery system in Africa. Afr J Trad Complem Altern Med 2005;2:46-61.

19. Schmelzer GH, Gurib-Fakim A. The Plant Resources of Tropical Africa 11(2): Medicinal Plants 2. Wageningen: Plant Resources of Tropical Africa; 2008.

20. Schmelzer GH, Gurib-Fakim A. The Plant Resources of Tropical Africa 11(2): Medicinal Plants 2. Wageningen: Plant Resources of Tropical Africa; 2013.

21. Van Wyk BE, Van Oudtshoorn B, Gericke N. Medicinal Plants of South Africa. Pretoria: Briza Publications; 2009.

22. Maroyi A. Ethnobotanical study of medicinal plants used by people in Nhema communal area, Zimbabwe. J Ethnopharmacol 2011;136:347-54.

23. Maroyi A. Garden plants in Zimbabwe: Their ethnomedicinal uses and reported toxicity. Ethnobot Res Appl 2012;10:45-57.

24. Maroyi A. Traditional use of medicinal plants in south-central Zimbabwe: Review and perspectives. J Ethnobiol Ethnomed 2013;9:31.

25. Dzoyem JP, Tshikalange E. Medicinal Plant Research in Africa. Oxford: Elsevier; 2013.

26. Kuete V. Medicinal Plant Research in Africa: Pharmacology and Chemistry. Oxford: Elsevier; 2013.

27. Iwu M. Handbook of African Medicinal Plants. Boca Raton: CRC Press; 2014

28. Maroyi A, Mosina GK. Medicinal plants and traditional practices in peri-urban domestic gardens of the Limpopo province, South Africa. Indian J Indigen Knowl 2014;13:665-72.

29. Maroyi A, Cheikhyoussef A. A comparative study of medicinal plants used in rural areas of Namibia and Zimbabwe. Indian J Indigen Knowl 2015;14:401-6. 
30. Van Wyk BE. A review of commercially important African medicinal plants. J Ethnopharmacol 2015;176:118-34

31. Neffati M, Najjaa H, Mathé A. Medicinal and Aromatic Plants of the World: Africa. Vol. 3. Leide: Springer; 2017.

32. Athipornchai A. A review on Tabernaemontana spp.: Multipotential medicinal plant. Asian J Pharmaceut Clin Res 2018;11:45-53.

33. Maroyi A. Dicomaanomala sond.: A review of its botany, ethnomedicine, phytochemistry and pharmacology. Asian J Pharmaceut Clin Res 2018;11:70-7.

34. Long, C. Swaziland's Flora: siSwati Names and Uses; Swaziland National Trust Commission: Mbambane, Swaziland, 2005; Available from: http://www.sntc.org.sz/index.asp. [Last accessed on 2017 Dec 11]

35. Van Wyk BE, Gericke N. People's Plants: A Guide to Useful Plants of Southern Africa. Pretoria: Briza Publications; 2007.

36. Dzomba P, Chayamiti T, Togarepi E. Heavy metal content of selected raw medicinal plant materials: Implication for patient health. Bull Environ Pharmacol Life Sci 2012;1:28-33.

37. Christenhusz MJ, Byng JW. The number of known plants species in the world and its annual increase. Phytotaxa 2016;261:201-17.

38. Palmer E, Pitman N. Trees of Southern Africa Covering all Known Indigenous Species in the Republic of South Africa, South-West Africa, Botswana, Lesotho and Swaziland. Cape Town: Balkema; 1972.

39. Schmidt E, Lotter M, McCleland W. Trees and Shrubs of Mpumalanga and Kruger National Park. Johannesburg: Jacana Media; 2002.

40. Wannan BS. Analysis of generic relationships in anacardiaceae. Blumea 2006;51:165-95.

41. Pell SK, Mitchell JD, Miller AJ, Lobova TA. Anacardiaceae. In: Kubitzki K, editor. The Families and Genera of Vascular Plants: Flowering Plants Eucodicotssapindales, Cucurbitales and Myrtaceae. Vol. X. London: Springer; 2011. p. 7-50.

42. Palgrave CM. Keith Coates Palgrave Trees of Southern Africa. Cape Town: Struik Publishers; 2002.

43. Van Wyk BE, Van Wyk P. Field Guide to Trees of Southern Africa. Cape Town: Struik Publishers; 1997.

44. Fernandes RB, Fernandes A. Anacardiaceae. In: Exell AW, Fernandes A, Wild H, editors. Flora Zambesiaca: Mozambique, Malawi, Zambia, Rhodesia, Bechuanaland Protectorate. Vol. 2. London: Crown Agents for Overseas Governments and Administrations; 1966. p. 550-615.

45. Germishuizen G, Meyer NL. Plants of Southern Africa: An Annotated Checklist. Strelitzia 14. Pretoria: National Botanical Institute; 2003.

46. Setshogo MP, Venter F. Trees of Botswana: Names and distribution. Pretoria: Southern African Botanical Diversity Network Report No. 18; 2003.

47. Da Silva MC, Izidine S, Amude AB. A preliminary checklist of the vascular plants of Mozambique. Pretoria: Southern African Botanical Diversity Network Report No. 30; 2004.

48. Setshogo MP. Preliminary Checklist of the Plants of Botswana. Pretoria: Southern African Botanical Diversity Network Report No. 37; 2005.

49. Figueiredo E, Smith GF. Plants of Angola. Strelitzia 22. Pretoria: South African National Biodiversity Institute; 2008

50. Hyde MA, Wursten BT, Ballings P, Palgrave CM. Flora of Zimbabwe: Species information: Lanneadiscolor (Sond.) England; 2018. Available from: https://www.zimbabweflora.co.zw/speciesdata/species.php?species $\mathrm{id}=136520$. [Last retrieved on 2018 Apr 13].

51. Fowler DG. Traditional Ila plant remedies from Zambia. Kirkia 2002;18:35-48.

52. Morris B. Chewa Medical Botany: A Study of Herbalism in Southern Malawi. Hamburg: Lit Verlag; 1996.

53. Bruschi P, Morganti M, Mancini M, Signorini MA. Traditional healers and laypeople: Aqualitative and quantitative approach to local knowledge on medicinal plants in Muda (Mozambique). J Ethnopharmacol 2011;138:543-63.

54. Chinsembu KC. Ethnobotanical study of plants used in the management of HIV/AIDS-related diseases in Livingstone, southern province, Zambia. Evid Based Complement Alternat Med 2016;2016:4238625.

55. Chinsembu KC, Hijarunguru A, Mbangu A. Ethnomedicinal plant sused by traditional healers in the management of HIV/AID Sop port unistic diseases in Rundu, Kavango East Region, Namibia. 2015. S Afr J Bot 2015;100:33-42.
56. Palgrave KC. The Trees of Central Africa. Salisbury: National Publications Trust; 1957.

57. Arnold HJ, Gulumian M. Pharmacopoeia of traditional medicine in Venda. J Ethnopharmacol 1984;12:35-74.

58. Mabogo DE. The Ethnobotany of the Vhavenda. MSc Dissertation, Pretoria: University of Pretoria; 1990

59. Hutchings A, Scott AH, Lewis G, Cunningham AB. Zulu Medicinal Plants: An Inventory. Pietermaritzburg: University of Natal Press; 1996.

60. Chigora P, Masocha R, Mutenheri F. The role of indigenous medicinal knowledge (IMK) in the treatment of ailments in rural Zimbabwe: The case of Mutirikwi communal lands. J Sustain Dev Afr 2007;9:26-43.

61. Ndamba J, Nyazema N, Makaza N, Anderson C, Kaondera KC. Traditional herbal remedies used for the treatment of urinary schistosomiasis in Zimbabwe. J Ethnopharmacol 1994;42:125-32.

62. Kazembe T, Munyarari E, Charumbira I. Use of traditional herbal medicines to cure malaria. Bull Environ Pharmacol Life Sci 2012;1:63-85

63. Maroyi A. Treatment of diarrhoea using traditional medicines: Contemporary research in South Africa and Zimbabwe. Afr J Tradit Complement Altern Med 2016;13:5-10.

64. Semenya SS, Maroyi A. Medicinal plants used by the Bapedi traditional healers to treat diarrhoea in the Limpopo Province, South Africa. J Ethnopharmacol 2012;144:395-401

65. Van Puyvelde L, Geiser I, Rwangabo PC, Sebikali B. Rwandese herbal remedies used against gonorrhoea. J Ethnopharmacol 1983;8:279-86.

66. Mølgaard P, Nielsen SB, Rasmussen DE, Drummond RB, Makaza N, Andreassen J. Anthelmintic screening of Zimbabwean plants traditionally used against schistosomiasis. J Ethnopharmacol 2001;74:257-64.

67. Mabona U, Viljoen A, Shikanga E, Marston A, Van Vuuren S. Antimicrobial activity of southern African medicinal plants with dermatological relevance: From an ethno pharmacological screening approach, to combination studies and the isolation of a bioactive compound. J Ethnopharmacol 2013;148:45-55.

68. Kabongo-Kayoka PN, Eloff JN, Obi CL, McGaw LJ. Antimycobacterial activity and low cytotoxicity of leaf extracts of some African anacardiaceae tree species. Phytother Res 2016;30:2001-11.

69. Chakuma N, Chipurura B, Muchuweti M, Chitindingu K, Bhebhe M, Chagonda L. (2015). Total phenolic content, free radical scavenging and antioxidant potential of Lanneadiscolor (Sond.) Engl bark and root extracts. J Biologically Active Prod Nat 2015;5:71-7.

70. Clarkson C, Maharaj VJ, Crouch NR, Grace OM, Pillay P, Matsabisa MG, et al. In vitro antiplasmodial activity of medicinal plants native to or naturalised in South Africa. J Ethnopharmacol 2004;92:177-91.

71. Nyoni M, Muzemu S, Chinheya C, Mushayabasa T, Ncube B. Screening Indigenous Nematicidal Plants in Zimbabwe Against Meloidogyne javanica. Paper Presented at a Conference Held on the $14^{\text {th }}-16^{\text {th }}$ July 2015 , Elephant Hills Resort, Victoria Fallls, Zimbabwe. Available from: http:// www.ir.msu.ac.zw:8080/jspui/bitstream/11408/1319/1/muzemu.pdf.

72. Maroyi A. Use of ethnomedicinal herbs to treat and manage schistosomiasis in Zimbabwe: Past trends and future directions. In: Martinez JL, Munoz-Acevedo A, Rai M, editors. Ethnobotany: Application of Medicinal Plants. London: CPC Press; 2018. p. 36-47.

73. Becker K, Lohrmann J. Feed selection by goats on tropical semi-humid rangeland. Small Rum Res 1992;8:285-98.

74. Würger G, McGaw LJ, Eloff JN. Tannin content of leaf extracts of 53 trees used traditionally to treat diarrhoea is an important criterion in selecting species for further work. S Afr J Bot 2014;90:114-7.

75. Tchounwou PB, Yedjou CG, Patlolla AK, Sutton DJ. Heavy metal toxicity and the environment. In: Luch A, editor. Molecular, Clinical and Environmental Toxicology. Experientia Supplementum. Vol. 101. Basel: Springer; 2012. p. 133-64.

76. Chang LW, Magos L, Suzuki T. Toxicology of Metals. Boca Raton: CRC Press; 1996.

77. Street RA. Heavy metals in medicinal plant products: An African perspective. S Afr J Bot 2012;82:67-74

78. Shaban NS, Abdou KA, Hassan NE. Impact of toxic heavy metals and pesticide residues in herbal products. Beni-SuefUniversity. J Basic Appl Sci 2016;5:102-6. 